Volume 7 Issue 2, June 2020

Nationally Accredited Journal,

Decree No. B/4130/E5/E5.2.1/2019

\title{
The Existence Of The Sale And Purchase Agreement (PPJB) As Authentic Evidence Tool Based On Government Regulation No. 24 Of 2016 On The Position Rules Of Land Deed Official Position In Cilacap Regency
}

\begin{abstract}
Basuki $^{1}$, Wildan Auliya ${ }^{2}$ and Ngadino $^{3}$
Abstract. The purpose of this study was to: 1) To analyze the implementation of the Agreement manufacture Sale and Purchase of Land by the Land Deed Official (PPAT). 2) To analyze the existence of the Sale and Purchase Agreement (PPJB) as Authentic Evidence based on Government Regulation No. 24 of 2016 Concerning the Rules of Land Deed Official Position in Cilacap Regency. 3) To know and analyze the process of land registration with the Sale and Purchase Agreement (PPJB) as Authentic Evidence. This study using sociological or empirical juridical approach. In sociological juridical approach of law as law in action, described as a social phenomenon that is empirical, descriptive analysis specifications. The data collection was obtained by interview and literature.

The research results are: 1 ) In the implementation of the keel PPJB included power from seller to buyer to sign the Sale and Purchase Agreements, so that the signing of the Sale and Purchase Agreements do not require the presence of the seller. PPJB is not paid, the payment is made if the selling price received by the seller has not paid off. In the chapters PJB not paid at least the specified amount of advance paid at the time of signing the deed of CHD, ways or terms of payment, when repayment and the agreed sanctions if one party defaults. PJB not paid off must also be followed by AJB at settlement. 2) the PPJB is binding for both parties (seller and buyer) as well as for the heirs or assigns who died.

Keywords: PPJB; Authentic Evidence; Deed of Sale and Purchase.
\end{abstract}

\section{Introduction}

Increased demand for land with increasingly limited land supply at this time, also have a major impact for the increase in value and the price of land. The increasing complexity of the problems of human life caused by the current land requires that there is a rule governing the legal guarantee in the relationship between man and land. ${ }^{4}$

To create the legal certainty of land, the government issued Act No. 5 of 1960 on Basic Regulation of Agrarian known as BAL. The government held land registration has been registered against the land further provided proof of land rights, and the evidence is strong evidence of the ownership of the land or that we are familiar with the certificate of land rights. ${ }^{5}$

According to article 1, paragraph (1) of Government Regulation No. 24 of 2016, PPAT is a public official who is authorized to make the deeds of authentic regarding certain

\footnotetext{
${ }^{1}$ Students of Master of Notary Program, Faculty of Law, Sultan Agung Islamic University (UNISSULA), Semarang, email: basuki1122@gmail.com

${ }^{2}$ Student of Master of Law Program, Faculty of Law, Universitas Islam Sultan Agung email wildanauliya1@gmail.com

${ }^{3}$ Notary / PPAT in Semarang, email: ngadinod238@gmail.com

${ }^{4}$ Dyara Radhite Oryza Fea, 2018, Panduan Mengurus Tanah Rumah dan Perizinannya, Legality, Yogyakarta, p. 2

${ }^{5}$ Ibid, p. 90
} 
legal actions regarding land rights or ownership of the apartment units. ${ }^{6}$ Legal act in question is a sale and purchase, exchange, donation, inclusion into the company (inbreng), the division of joint property, granting building rights, land use rights or property rights, the provision of security rights, and giving the authority to the security rights.

Sale and purchase according to the Civil Code is an agreement in which one party (the seller) to bind himself to hand (property rights) of an object and the other party (the buyer) to pay the price that has been promised under Article 1457. The sale and purchase under Section 1458 are considered have taken place between the two sides at the time achieved consensus on the objects sold along with the price even if the object has not been submitted and the price has not been paid. With the purchase, the land ownership has not been transferred to the buyer even though the price has been paid and the land was handed over to the buyer. ${ }^{7}$ However, to bind third parties, including the Government, after the purchase before PPAT, must be registered in advance. The purpose of the maker of Sale and Purchase Agreements (AJB) by PPAT is as a condition of transfer of rights or titling of land registration in the Land Office.

Sale and Purchase Agreement which are not specifically regulated in the Civil Code as well as purchase and sale agreement with experiment as set forth in Article 1463 of the Civil Code and the sale with repurchase under Article 1519 of the Civil Code. However, based on a system of openness and the principle of freedom of contract, it can be held binding sale and purchase agreement by relying on the provisions of Article 1338 paragraph (1) of the Civil Code. The binding sale and purchase is an agreement between the seller and the buyer before the sale and purchase due to the implementation of the elements that must be met for the sale and purchase of these include certificates yet because it is still in the process of, or has not happened redemption price. ${ }^{8}$

In Cilacap Regency, in the practice of buying and selling land rights to the object they are buying and selling practices are preceded by a treaty called the Sale and Purchase Agreement or in terms of the practice of so-called PPJB. Sale and Purchase Agreement (PPJB) is one form of engagement that was born because of the needs of society, it is because it can not fulfill the requirements to carry out the sale and purchase before the Land Deed Official (PPAT). Agreements Sale and Purchase Agreement (PPJB) which Notary is an agreement that was appointed and made of Conception of the Civil Code which is an agreement between the parties regarding the rights and obligations made under Article 1320 in conjunction with Article 1338 of the Civil Code in order to provide legal certainty and legal protection for the parties that makes it.

The problem is to register the transfer of rights through the sale and purchase of the Land Office must use an authentic deed PPAT form Sale and Purchase Agreements (AJB) as stipulated in Government Regulation No. 24 of 2016 Concerning the Rules of Land Deed Official Position. So as to status or the buying and selling land and buildings that are still binding Sale and Purchase Agreement (PPJB), the Office of Defense has not been able to carry out the registration process. Based on the aforementioned problems, were interested to analyze a study entitled "The existence of the Sale and Purchase Agreement (PPJB) as Authentic Evidence Tool Based on Government

\footnotetext{
${ }^{6}$ Article 1 (1) of Government Regulation No. 24 of 2016 on regarding Amendment to Government Regulation No. 37 of 1998 on the Land Deed Official Rules

${ }^{7}$ Adrian Sutedi, 2012, Sertifikat Hak Atas Tanah, Sinar Grafika, Jakarta, p. 129

${ }^{8}$ Subekti, 2002, Hukum Perjanjian, Ed. 19, PT. Intermasa, Jakarta, p. 17
} 
Volume 7 Issue 2, June 2020

Nationally Accredited Journal,

Decree No. B/4130/E5/E5.2.1/2019

Regulation No. 24 of 2016 Concerning the Rules of Land Deed Official Position in Cilacap Regency"

This study tried to answer the question regarding the manufacturing operations Treaty Sale and Purchase of Land by Deed Official Land (PPAT), the existence of agreements Sale and Purchase Agreement (PPJB) as Authentic Evidence under Government Regulation No. 24 of 2016 About the Position Rules Deed Official Land in the Cilacap Regency.

\section{Research methods}

The approach used in this study is juridical sociological or empirical. In sociological juridical approach of law as law in action, described as an empirical social phenomena. Sociological juridical approach is intended as an application and assessment of legal aspects of relations with non-legal aspects of the working of the law in society. Legal research sociological research follows the pattern of the social sciences, especially sociology so this research is called socio legal research. ${ }^{9}$ Data were collected by interview and review of the literature.

\section{Results and Discussion}

\subsection{Implementation of the Sale and Purchase Agreement on Manufacture Land By The Land Deed Official (PPAT)}

One way of acquisition of land which is often done by buying and selling. In selling, there are two legal subjects of the seller and buyer, which each have rights and obligations, then each of them in some ways is a party to perform an obligation, and in other matters is the party that received the right. This relates to the reciprocal nature of the purchase agreement (werdering overeenkomst). ${ }^{10}$

Sale and purchase of land under customary law must meet three (3) elements, namely cash, real, and bright. The definition of "cash" means the transfer of rights by the seller carried out simultaneously with the payment by the buyer and at once the rights have already switched. The price paid was not to be paid, the difference in price considered as debt buyers to sellers that included the scope of accounts payable. Are "real" means the will of the spoken must be followed real acts such as by receipt of money by the seller, and made a covenant before the village head. Is "bright" if carried out in the presence of village heads to ensure that the act does not violate the law. ${ }^{11}$

Fulfillment of the requirements have not been buying and selling of land rights is a legal act which is made in the presence of PPA, we need a binding written agreement is authentic in order to have the legality of which can provide protection and legal certainty of the parties, especially the buyer. Authentic deeds as the strongest evidence and filled an important role in any legal relationship in the life of society. A public official authorized to make the authentic act under the legislation include the notary and PPAT.

Agreements can be made before it can be made AJB is PPJB. PPJB divided into two (2) types, namely:

\footnotetext{
${ }_{9}^{9}$ Amiruddin, 2012, Pengantar Metode Penelitian Hukum, RajaGrafindo Persada, Jakarta, p. 15

${ }^{10}$ Zainal Idris, 2004, Ketentuan Jual Beli Memuat Hukum Perdata, Faculty of USU Medan, p.36

11 Maria SWSumardjono, 2001, Kebijakan Pertanahan Antara Regulasi dan Implementasi, Kompas, Jakarta, p.119
} 
- PPJB new Deed are promises because usually the price has not been fully paid by the buyer but still repaid in several installments, referred to as the PPJB fullpaid yet.

- Deed PPJB which payment has been made in full but not yet implemented the manufacture of the deed of sale purchasing before PPAT authorized, because it has not fulfilled the requirements and reasons which led AJB can not be made known as PPJB fullpaid.

Although both have different backgrounds in principle, are paid whether or not the purchase price, but in deed PPJB both are binding, both for the parties and for the heirs or assigns who died. ${ }^{12}$ Some of the things that must be considered in the implementation of the PPJB in general, among others:

- Description of ground objects and buildings should be obvious, such as the vast size of land and buildings (if necessary accompanied by a map of plots of land and architecture of the building), certificates and the rights holder, and of licenses attached to the object land and the building.

- The price of land per meter and the total price as well as the method of payment. Paying the price of land may also be determined gradually and repayment made at the signing AJB.

- Terms specific canceled, for example, if it turns out the construction of his house was not in accordance with the time period promised the developer, then the prospective buyer is entitled to cancel and receive back the advance. Or if the construction was completed on time but the prospective buyer to cancel it unilaterally, then the potential buyer will lose the down payment.

- Affirmation of the tax payment obligations of each party and other costs required, eg land surveying costs and the cost Notary / PPAT.

- If you need to put the representations and warranties clause of the prospective sellers namely, that the sale of land that are not in a third party loan guarantees or involved in legal disputes. If it turns out the prospective seller representations and warranties were not true, then the prospective seller will relieve prospective buyers of any other party demands.

PPJB according R.Subekti is an agreement between the seller and buyer before the sale and purchase due to the implementation of the elements that must be met for the sale and purchase, among others, is the certificate of land rights because there has been no progress, or has not the price or tax repayment -tax imposed on the sale and purchase of land rights can not be paid either by the seller or the buyer. ${ }^{13}$

In the implementation of the keel PPJB also included power from seller to buyer to sign the Sale and Purchase Agreements, so that the signing of the Sale and Purchase Agreements do not require the presence of the seller. Sale and Purchase Agreement keel common for transactions sale and purchase of objects that are outside the working area of a notary or PPAT concerned. Under the Sale and Purchase Agreement can be made in full before the Deed of Sale and Purchase Deed Official Land in locations where the object is located. PPJB is not paid, the payment is made if the selling price received by the seller has not paid off. In the chapters listed minimum PJB not paid an advance amount paid at the time of signing the deed of CHD, ways or terms of payment, when repayment and the agreed sanctions if one party defaults.

\footnotetext{
12 Dony Hadirusdianto 2009, Beberapa Catatan Penting Tentang Pengikatan Jual Beli Hak Atas Tanah, Mitra Ilmu, Jakarta, p.12

${ }^{13}$ Subekti, 1987, Hukum Perjanjian, Bina Cipta, Bandung. p.75
} 
Volume 7 Issue 2, June 2020

Nationally Accredited Journal,

Decree No. B/4130/E5/E5.2.1/2019

\subsection{The existence of the Sale and Purchase Agreement (PPJB) as Authentic Evidence based on Government Regulation No. 24 of 2016 Concerning the Rules of Land Deed Official Position in Cilacap Regency}

In practice, many people make buying and selling of land rights is one of the legal acts pertaining to land rights in cash or paid off more frequently use the Sale and Purchase Agreement (PPJB) due to various factors or reasons. But is not the buying and selling must be done in the presence of PPAT. This is in accordance with article 37 paragraph (1) of Government Regulation No.24 of 1997 on the ownership of flats through purchase, exchange, donation, inclusion in the company and other legal acts of transfer, unless assignment through auction, can only be registered, if evidenced by a deed made by PPAT authorized under the provisions of the legislation in force.

As one example is the purchase of land in full but buyers can not be filed under the name of the Land Office because the certificate still the parent, so the certificate should applied solving first. Due to the sale and purchase already made in cash and just using the regular receipt sheet before it can be made AJB before PPAT, the parties agree to make a purchase and sale agreement made before Notary Deed in the form of the PPJB and the power to sell. But after he made Deed CPPJB and the power to sell, the seller died and still in the process of solving the Land Office. With the death of the seller after he made the PPJB and the power to sell, the buyer can register ownership of their land rights and legal protection as according to Article 37 paragraph (1) PP

In addition, in practice also often encountered people who deliberately make PPJB before a notary at the time of the sale and purchase of land rights, despite the fact that already qualified for making AJB. The buyer was not immediately make the grounds AJB will sell more land that has been bought. Then the buyer makes the PPJB and the power to sell to another party. So that there is the PPJB and the power to sell more than one or terraced. PPJB is an agreement under civil law is divided into two forms, namely in the form of sale and purchase are tied with agreements under the hand, and created an authentic deed. Differences were stressed on the strength of evidence. According to Article 1868 of the Civil Code an authentic deed is a deed in the prescribed form of legislation, made by or in the presence of public servants in power to it in a place where the deed made. PPJB can be made before a notary public as officials who have the authority to make the authentic act under the law.

PPJB is binding for both parties (seller and buyer) as well as for the heirs or assigns who died. It is included in the PPJB clause. Clause reads "The binding purchase will not be canceled due to the death of one of the parties but declined and apply continue to heirs or assignee of the deceased and hence the heirs or beneficiaries of such rights must fulfill all the conditions set in the deed of sale and purchase of this binding, until the achievement of the purpose and objective of the PPJB made this deed. "With the existence of these clauses then in the event of the death of events seller then all heirs must submit to the treaty agreed in advance.

In the keel PPJB then each made the PPJB should be followed by the power sold from the seller to the buyer. So when all the requirements are met, without the presence of the seller because it is already represented, given power to sell to buyers. According to Article 1792 of the Civil Code power of attorney is an agreement by which a person give power or authority to another person, who received it, for in his name conducting an affair. An affair is only for legal actions. 
Power to sell, fit into the category of special powers that are used to transfer the objects, which in essence can only be done by the owner only. Therefore, for the power to sell, need a power of attorney with the words firmly in the deed (article 1796 of the Civil Code).

Deed PPJB and selling power is also an inseparable pair. Two certificates were not contradictory, even complementary. ${ }^{14}$ It also means that the PPJB and the selling power is unity. Authorization to sell in the PPJB aim to provide guarantees or protection to the authorized person (buyer), after the conditions that are required in the sale and purchase of land filled, to be able to carry out their own rights that arise in a binding sale and purchase or signing himself AJB without the presence of the giver power (sellers) in the presence of PPAT.

Legal protection given PPJB keel and the power to sell to the buyer when the seller dies very strong and perfect because of the nature of evidence of the PPJB and the power to sell, made before a public official in this case a notary. It is a form of legal certainty and as a form of legal protection for buyers who have paid the price already pays in full but can not be implemented manufacture and registration AJB behind its name because of one reason or another there are conditions that have not been fulfilled. Besides having a strong evidentiary nature and perfect, with the establishment of the PPJB and sell power can also provide legal protection for the buyer as follows:

- Relating to taxes, the buyer does not bear the sales tax, if the seller has died at the signing of the PPJB, the Income Tax already paid off before the PPJB was signed it is based in Article 1 (3) letter a Government Regulation No.34 of 2016 regarding Income Tax on income from Transfer of Rights to Land and / or buildings, and the Sale and Purchase Agreement on Land And / Or Building Along with its amendment. Because prior to the entry into force of this regulation in practice, at the time of making the PPJB and sale right no income tax is paid in advance so that if the seller had died that bear the income tax is the purchaser, and habitually new income tax paid at the time of manufacture AJB.

- Legally ownership can be proved by the PPJB and the power to sell the Notary very strong, if the seller dies heir can not interfere with accountability for ownership of the land even though the land has not been made AJB. Because the heir must be subject to the provisions of clause PPJB and selling power.

PPJB and power sold were made based on Article 1338 of the Civil Code is an agreement that is legally valid as laws PPJB is an agreement like in general, the agreement is an act in which one or more persons bind himself to one other person or more (Article 1313 Civil Code) , CPPJB was born due to the open nature of Book III of the Civil Code Article 1338 which make agreements that contain any extent not inconsistent with law, order, and norms of decency. Either a legal contract made under the arms and the authentic act if it meets the requirements set forth in Article 1320 of the Civil Code the agreement for those that bind himself, able to make a commitment, a certain thing, and a cause that kosher give freedom as possible to the subject of law to an agreement which contains any extent not inconsistent with law, order, and norms of decency. PJB Notary is an authentic deed. Notary is a public official authorized to make an authentic deed as far as the manufacture of authentic deeds are not excluded for other public officials. Making the authentic act is required by legislation in order to create certainty, order and legal protection. Notary is a public official authorized to make an authentic deed as far as the manufacture of authentic deeds are not excluded for other public officials. Making the authentic act is required

${ }^{14}$ A.Kohar, 1984, Notaris Berkomunikasi, Alumni, Bandung, p.11 
Volume 7 Issue 2, June 2020

Nationally Accredited Journal,

Decree No. B/4130/E5/E5.2.1/2019

by legislation in order to create certainty, order and legal protection. Notary is a public official authorized to make an authentic deed as far as the manufacture of authentic deeds are not excluded for other public officials. Making the authentic act is required by legislation in order to create certainty, order and legal protection. ${ }^{15}$

\section{Closing}

\subsection{Conclusion}

Based on the description above, the conclusions of this research are:

- Manufacturing operation Agreements Sale and Purchase of Land by Deed Official Land (PPAT) should pay attention to the following: Description of ground objects and buildings must be clear, land price per meter and the total price of the whole as well as the method of payment, terms null particular, the assertion of tax payments the obligation of each party and other costs required. In the implementation of the keel PPJB also included power from seller to buyer to sign the Sale and Purchase Agreements, so that the signing of the Sale and Purchase Agreements do not require the presence of the seller. Under the Sale and Purchase Agreement can be made in full before the Deed of Sale and Purchase Deed Official Land in locations where the object is located. PPJB is not paid, the payment is made if the selling price received by the seller has not paid off. In the chapters PJB not paid at least the specified amount of advance paid at the time of signing the deed of CHD, ways or terms of payment, when repayment and the agreed sanctions if one party defaults. PJB not paid off must also be followed by AJB at settlement.

- Existence Agreements Sale and Purchase Agreement (PPJB) as Authentic Evidence under Government Regulation No. 24 Year 2016 About the Position Rules Deed Official Land in Cilacap Regency, namely the PPJB is binding for both parties (seller and buyer) as well as for the heir or the assignee who died. It is included in the PPJB clause. Clause reads binding sale and purchase will not be canceled due to the death of one of the parties but declined and apply continue to heirs or assignee of the deceased and hence the heirs or assigns must comply with all the provisions set forth in binding deed of sale and purchase, up to the achievement of the purpose and objective of the PPJB made this deed.

\subsection{Suggestion}

- In making the Deed of Sale and Purchase Agreement, the notary should include clauses that complete and clear in order to provide legal protection for prospective sellers and prospective buyers.

- For the community, it should not use the Deed of Sale and Purchase Agreement as an attempt to evade taxes because it can harm the state.

- For the government, should be able to give a clearer arrangement regarding the Deed of Sale and Purchase Agreement in positive law in Indonesia.

\section{References}

\section{[1] A.Kohar, 1984, Notaris Berkomunikasi, Alumni, Bandung}

\footnotetext{
${ }^{15}$ Gunardi and Gunawan, 2007 Kitab Undang-Undang Hukum Kenotariatan, Himpunan Peraturan tentang Kenotariatan, Raja Grafindo Persada, Jakarta, p.ix.
} 
[2] Adrian Sutedi, 2012, Sertifikat Hak Atas Tanah, Sinar Grafika, Jakarta

[3] Amiruddin, 2012, Pengantar Metode Penelitian Hukum, RajaGrafindo Persada, Jakarta

[4] Dony Hadirusdianto 2009, Beberapa Catatan Penting Tentang Pengikatan Jual Beli Hak Atas Tanah, Mitra Ilmu, Jakarta

[5] Dyara Radhite Oryza Fea, 2018, Panduan Mengurus Tanah Rumah dan Perizinannya, Legality, Yogyakarta

[6] Gunardi and Gunawan, 2007, Kitab Undang-Undang Hukum Kenotariatan, Himpunan Peraturan tentang Kenotariatan, RajaGrafindo Persada, Jakarta

[7] Zainal Idris, 2004, Ketentuan Jual Beli Memuat Hukum Perdata, Faculty of USU Medan

[8] Maria SWSumardjono, 2001, Kebijakan Pertanahan Antara Regulasi dan Implementasi, Kompas, Jakarta

[9] Government Regulation No. 24 of 2016 on regarding Amendment to Government Regulation No. 37 of 1998 on the Land Deed Official Rules

[10] Subekti, 2002, Hukum Perjanjian, Ed. 19, PT. Intermasa, Jakarta 